\title{
Genome Size and Base Composition of Deoxyribonucleic Acid from Eight Human T-Mycoplasmas
}

\author{
FINN T. BLACK, CLAUS CHRISTIANSEN, and GERD ASKAA \\ Institute of Medical Microbiology, University of Aarhus, DK-8000 Aarhus, Denmark
}

\begin{abstract}
The base compositions of the deoxyribonucleic acid and the genome sizes of eight serotypes of human $\mathrm{T}$-mycoplasmas are reported. The guanine plus cytosine contents, as measured by thermal denaturation and $\mathrm{CsCl}$ gradient centrifugation, are 27 to $28 \%$, the latter method giving slightly lower values. The genome sizes are within the range of $4.1 \times 10^{8}$ to $4.8 \times 10^{8}$ daltons, which corresponds to the values found for members of the family Mycoplasmataceae.
\end{abstract}

A previous study (1) of the guanine plus cytosine (GC) content of the deoxyribonucleic acid (DNA) from seven human T-mycoplasmas showed only minor differences among serologically distinct strains. The values ranged from 27.7 to $28.5 \% \mathrm{GC}$ as determined from melting profiles. Also, determination of the genome size of two serotypes (strain 27 and strain 58) of human T-mycoplasmas suggested the existence of some homogeneity within the group (2).

The purpose of this study was: (i) to determine the GC content of the well-known strain T-960, (ii) to compare the GC contents of the human T-mycoplasmas as measured by melting temperature $\left(T_{\mathrm{m}}\right)$ and buoyant density, and (iii) to extend the knowledge of genome sizes to all known serotypes of human T-mycoplasmas.

\section{MATERIALS AND METHODS}

Organisms. The strains investigated are listed in Table 1. T-960 was received from J. G. Tully, Bethesda, Md., USA, and the remaining strains were from D. K. Ford, Vancouver, B.C.

Cultivation and DNA extraction. The organisms were grown in a modified liquid Shepard's medium, and the DNA was extracted as previously described (1).

Determination of GC content and genome size. Determination of buoyant density was done by the method of Schildkraut et al. (7) with DNA extracted from Escherichia coli B used as a reference (density $1.710 \mathrm{~g} / \mathrm{cm}^{3}$ ). The melting temperature of DNA from T-960 was determined as previously described (1). Genome size determination was made by the method of Wetmur and Davidson (9) with the modifications described by Bak et al. $(2,3)$.

\section{RESULTS}

The base compositions of the DNA are given in Table 1. Strain T-960 has a GC content of $27.6 \% \mathrm{GC}$ (from $T_{\mathrm{m}}$ ) and $27.1 \% \mathrm{GC}$ (from buoyant density). These values are within the range of those found for other human $T$ mycoplasmas.

The GC contents as calculated from the buoyant densities are in the range of 26.9 to $28.0 \mathrm{~mole} \% \mathrm{GC}$. This is in accord with the results obtained by the $T_{\mathrm{m}}$ method (reference 1 , given in Table 1), although the latter appears to give slightly higher values (mean differences, $0.6 \% \mathrm{GC}$ ).

The calculated genome sizes are listed in Table 2. The values vary from $4.1 \times 10^{8}$ daltons (strain Pirillo) to $4.8 \times 10^{8}$ daltons (strain T-960). The measurements for strain 58 $\left(4.5 \times 10^{8}\right.$ daltons $)$ and strain $7\left(4.6 \times 10^{8}\right.$ daltons) are in excellent agreement with the values previously reported for these same strains (2). The mean value of the coefficient of variability throughout this series of determinations is 0.08 . Thus none of the genome sizes measured can be considered to differ from the mean value ( $4.45 \times 10^{8}$ daltons).

\section{DISCUSSION}

As seen from Table 1, the DNA from strain T-960 has a GC content equal to that of the other strains investigated. The GC contents, as measured by the two methods applied, also show good agreement.

The genome sizes (Table 2) are given as 
TABLE 1. Buoyant densities, melting temperatures, and base compositions of the DNA from eight human T-mycoplasmas

\begin{tabular}{l|c|c|c|c}
\hline & & & \multicolumn{2}{|c}{ GC content calculated from } \\
\cline { 3 - 4 } \multicolumn{1}{c|}{ Strain } & $\begin{array}{c}\text { Buoyant density } \\
\left(\mathrm{g} / \mathrm{cm}^{3}\right)\end{array}$ & $\begin{array}{c}\text { Melting temp } \\
(\mathrm{C})\end{array}$ & Buoyant density & $\mathrm{T}_{\mathrm{m}}{ }^{b}$ \\
\hline No. 7 & 1.687 & $80.85^{b}$ & 27.4 & 28.2 \\
No. 23 & 1.687 & 80.75 & 27.3 & 28.0 \\
No. 27 & 1.687 & 80.80 & 27.8 & 28.1 \\
No. 58 & 1.688 & 81.00 & 28.0 & 28.5 \\
No. 354 & 1.687 & 80.70 & 27.5 & 27.8 \\
Cook & 1.687 & 80.65 & 27.0 & 27.7 \\
Pirillo & 1.686 & 80.70 & 27.1 & 27.8 \\
T-960 & 1.687 & 80.65 & 27.6 \\
\hline
\end{tabular}

${ }^{a}$ The buoyant density was measured by using DNA from Escherichia coli B as a reference with a density of $1.710 \mathrm{~g} / \mathrm{cm}^{3}$.

${ }^{b}$ Previously reported (1) except for T-960.

TABLE 2. Genome sizes of human T-mycoplasmas

\begin{tabular}{l|c|c|c}
\hline Strain & $\begin{array}{c}\text { No. of deter- } \\
\text { minations }\end{array}$ & $\begin{array}{c}\text { Genome size } \times 10^{8} \\
\text { daltons }\end{array}$ & SD $^{b}$ \\
\hline No. 7 & 2 & 4.3 & 0.0 \\
No. 23 & 2 & 4.3 & 0.4 \\
No. 27 & 3 & 4.6 & 0.6 \\
No. 58 & 5 & 4.5 & 0.5 \\
No. 354 & 2 & 4.5 & 0.5 \\
Cook & 2 & 4.6 & 0.4 \\
Pirillo & 3 & 4.1 & 0.2 \\
T-960 & 2 & 4.8 & 0.4 \\
\hline
\end{tabular}

$a$ The genome sizes were calculated from the formula: $\mathrm{GC}=8.83 \cdot 10^{8} \cdot\left(S_{20}^{p \mathrm{H}} 7.0{ }_{\mathrm{w}} 0.911 / \mathrm{K}_{2}\right.$ (reference 3 ). The $S$ values varied in the experiments between 8.4 and 17.9 .

${ }^{b}$ SD, Standard deviation.

kinetic complexities without correction for the influence of the GC content of the DNA on the renaturation rate. Different corrections, based on measurements of known genomes, have been proposed for the calculation of genome sizes from kinetic complexities $(2,4,8,9)$. Seidler and Mandel ( 8 ) found that by their method of renaturation the kinetic complexity of DNA from Mycoplasma hominis (strain H 39) was two times the genome size measured by electron microscopy. However, Bak et al. (2), using a method identical to ours, also determined the kinetic complexity of $M$. hominis (strain PG 21), but they did not find disagreement between the two values. Taking into consideration the homogeneity in genome sizes within the Mycoplasmataceae (2), methodological differences rather than strain differences seem to be the explanation. The magnitude of any possible correction thus appears unclear.

In a previous study (2) it was shown that the genome sizes of the mycoplasmas varied in accordance with the requirement of sterols: the Acholeplasmataceae have genome sizes around $9 \times 10^{8}$ to $10 \times 10^{8}$ daltons, and the $\mathrm{Myco}^{-}$ plasmataceae, $4 \times 10^{8}$ to $5 \times 10^{8}$ daltons. The T-mycoplasmas investigated are all found to be within the range of $4 \times 10^{8}$ to $5 \times 10^{8}$ daltons, which is in agreement with their requirement for sterols (6). These results give further support for placing the T-mycoplasmas in the family Mycoplasmataceae.

\section{LITERATURE CITED}

1. Bak, A. L., and F. T. Black. 1968. DNA base composition of human T-strain mycoplasmas. Nature (London) 219:1044-1045.

2. Bak, A. L., F. T. Black, C. Christiansen, and E. A. Freundt. 1969. Genome size of mycoplasmal DNA. Nature (London) 224:1209-1210.

3. Bak, A. L., C. Christiansen, and A. Stenderup. 1970. Bacterial genome sizes determined by DNA renaturation studies. J. Gen. Microbiol. $64: 377-380$.

4. Gillis, M., J. De Ley, and M. de Cleene. 1970. The determination of molecular weight of bacterial genome DNA from renaturation rates. Eur. J. Biochem. 12:143-153.

5. International Committee on Nomenclature of Bacteria. Subcommittee on the Taxonomy of $\mathrm{Myco}$ plasmatales. 1971. Minutes of the Meeting. 10 August 1970. Int. J. Syst. Bacteriol. 21:151-153.

6. Rottem, S., E. A. Phendt, and L. Hayflick. 1971. Sterol requirements of T-strain mycoplasmas. $J$. Bacteriol. 105:323-330.

7. Schildkraut, C. L., J. Marmur, and P. Doty. 1962. Determination of the base composition of deoxyribonucleic acid from its buoyant density in CsCl. J. Mol. Biol. 4:430-443.

8. Seidler, R. J., and M. Mandel. 1971. Quantitative aspects of deoxyribonucleic acid renaturation: base composition, state of chromosome replication, and polynucleotide homologies. J. Bacteriol. 106:608-614.

9. Wetmur, J. G., and N. Davidson. 1968. Kinetics of renaturation of DNA. J. Mol. Biol. 31:349-370. 